\title{
DUHKHA DALAM CHANDOGYA UPANISAD \\ DAN CARA MENGATASINYA
}

\author{
Oleh
}

\author{
Made Joniarta \\ Akademisi IHDN Denpasar \\ E-mail: joniartamade11@gmail.com
}

\begin{abstract}
The main purpose of this work is to conduct an investigation deep into the truth that reaches the step when someone becomes wise and mature to decide from all karma. The Chändogya Upanișad text has been chosen to be studied in this study because this literature clearly explains the duhkha conception. The concept of duhkha in the Chāndogya Upanișad is a state of the soul that is materially bound to the physical body. When the soul is bound to the senses materially, it causes billions of desires to come out. All boundaries of these desires will throw the soul into the depths of grief (duhkha). The way to let go of the duhkha based on the Chandogya Upanisad by understanding the atman which covers the universe, will experience unlimited happiness. Truly unlimited God is He transcends all that is. Thus Chandogya Upanisad encourages everyone to know and appreciate the true nature of the self, to be released from Dukha.
\end{abstract}

Keywords: dukkha, Chandogya Upanisad, method

\section{ABSTRAK}

Tujuan utama dari tulisan suci ini adalah untuk melakukan penyelidikan jauh ke dalam kebenaran rumah terakhir yang mencapai langkah ketika seseorang menjadi agak bijak dan dewasa untuk memutuskan dia dari semua karma. Teks Chāndogya Upanișad telah dipilih untuk dikaji dalam penelitian ini karena pustaka ini menjelaskan dengan jelas tentang konsepsi duhkha. Konsep duhkha dalam Chāndogya Upanișad adalah keadaan jiwa yang terikat dengan tubuh fisik secara material. Ketika jiwa terikat dengan indera secara material, maka itu menyebabkan miliaran keinginan keluar. Semua batasan terhadap keinginan-keinginan ini akan melemparkan jiwa ke kedalaman duka (duhkha). Cara untuk melepaskan dari ikatan duhkha berdasarkan Chāndogya Upanișad dengan mengerti tentang atman yang meliputi alam semesta, akan mengalami kebahagian tidak terbatas. Karena sesungguhnya yang tidak terbatas itulah Tuhan sebab tuhan melampaui segala yang ada. Dengan demikian Chandogya Upanisad menganjurkan kepada setiap orang untuk mengetahui dan menghayati tentang hakikat sejati sang diri, untuk terlepas dari Dukha.

Kata Kunci: dukkha, Chandogya Upanisad, metode

\section{PENDAHULUAN}

Dalam filsafat India dinyatakan bahwa sekalipun ātman (jiwa atau inti diri) bebas secara abadi, namun ia terlibat dengan avidyā (ketidaktahuan atau kebodohan), dimana keterlibatan itu dikatakan tanpa awal (anadi), tetapi dapat diakhiri Ātman bersifat murni, ketika ia masuk ke dalam tubuh-tubuh yang bersifat materi kemurniannya tertutupi oleh materi. Namun, ātman yang ada didalam tetap murni hanya saja kemurnian itu tertutup oleh kekotoran materi. Seperti halnya permata yang jatuh dalam lumpur, ia akan menganggap dirinya sebagai lumpur. hal inilah yang menyebabkan kekeliruan, menyamakan dirinya dengan badan. Hal inilah yang menimbulkan pernyataan "saya orang Jawa", "saya orang Bali", "saya orang Bugis" dan lain sebagainya. Hal tersebut relevan dengan pernyataan Prabhupada (2003:43) menyatakan bahwa "penderitaan akan timbul apabila kita menyamakan diri dengan badan." Sang jiwa yang 
berada dalam tubuh tidak mengetahui hakikat sang diri sejati, ia hanya mengetahui badan fisiknya sehingga ia terbawa oleh pengaruhpengaruh duniawi. Hal inilah yang membuat penderitaan, penderitaan dapat menyebabkan keterikatan. Keterikatan ini yang memabukkan diri pada hal-hal duniawi, baik keluarga, kerabat, harta benda maupun tahta. Segala keterikatan ini akan menjebloskan jiwa dalam jurang kesedihan (duhkha). Segala jenis kesedihan akan dialami oleh sang jiwa ketika ia masih berada dalam siklus kelahiran dan kematian.

Menurut Wikipedia Pengertian Dukha merupakan istilah dalam bahasa Pali yang seringkali diartikan sebagai penderitaan, ketidakpuasan, kesedihan, kemalangan dan keputus-asaan. Menghentikan dukkha merupakan tujuan utama. Kelahiran adalah penderitaan; menjadi tua adalah penderitaan; penyakit adalah penderitaan; kematian adalah penderitaan; kesedihan, ratap tangis, rasa sakit, kesengsaraan (ketidaksenangan) dan keputusasaan adalah penderitaan; tidak memperoleh apa yang diinginkan adalah penderitaan. Dengan kata lain Lima kelompok kehidupan (Pancakhandha) yang dipengaruhi kemelekatan adalah penderitaan (dukkha).

Hal ini juga dibahas dalam Chāndogya Upanișad tentang terikatnya roh dalam badan yang bersifat material. Ketika roh diikat oleh indria-indria, maka berjuta-juta keinginan muncul. Segala keterikatan akan berbagai keinginan inilah yang menjebloskan jiwa dalam jurang kesedihan (duhkha). Ia akan selalu berbuat untuk memenuhi indriyanya, setiap perbuatan inilah yang mendukung sang jiwa mendapat berbagai jenis badan, ketika badan yang diperoleh menurun maka proses pencapaian kebebasanya pun akan semakin lama.

Bila kita memiliki tentang keyakinan hukum Karma Phala itu, maka sangat bermanfaat bagi kehidupan umat manusia, sebab di dalamnya terdapat aksioma, yaitu hukum yang tidak terbatalkan. Karma harus berlaku dan berlaku adil. Kemudian sebelum Phala itu kembali pada sumber Karma maka selama itu Phala tetap berproses menunggu waktu yang akan kembalinya menuju sumber Karma. Hal ini tidak ubahnya seperti gelombang yang ditimbulkan oleh lemparan batu ke dalam telaga. Sebelum gelombang itu balik ke pusat lemparan batu maka selama itu gelombang bergetar walaupun berakhir dengan getaran yang sangat halus. Demikianlah adanya gelombang itu berhenti bergetar setelah menuju dan berada pada pusat lemparan batu tadi. Dalam lukisan ini tampak akan kepastian hukum karma itu, phalanya kembali kepada si pembuat karma.

Dalam contoh lain, kita lihat bahwa phala selalu mengejar si pembuat karma, karena phala itu tidak bisa dipisahkan dengan karma. Tak ubahnya seperti badan dengan bayang-bayang. Kemana badan lari, ke situ juga bayang-bayang mengejarnya. Demikian juga halnya dengan orang berkarma buruk, mereka itu selalu dikejar oleh bayangan buruk, mungkinkah dosa ataukah yang lain? Demikian sebaliknya orang berkarma baik akan dikejar oleh bayangan baik.

Jadi, dapat ditegaskan kembali bahwa sangat beruntung adalah orang yang memiliki keyakinan, adanya kebenaran berlakunya hukum Karma Phala di dunia ini, sebab dengan memiliki keyakinan itu orang menjadi terkendali berkarma dan selalu mengarahkan hidupnya pada perbuatan yang baik. Perbuatan yang baik yakni perbuatan yang mengutamakan kepentingan, keselamatan dan kebahagian bersama. Selain itu mencerminkan nilai-nilai kemanusiaan, nilai-nilai agama, beramal dan bertanggung jawab. Sangatlah mustahil orang yang menanam padi akan menghasilkan jagung, atau orang yang menanam ubi akan menghasilkan gandum. Sudah pasti menanam padi, padilah hasilnya, dan yang menanam ubi, ubilah hasilnya. Jadi berkarma baik, baik juga phalanya dan berkarma buruk, buruk juga phalanya.

Dalam kehidupan sehari hari tidak dipungkiri Duhkha akan selalu hadir, kesedihan tidak 
dapat sepenuhnya dihindari, karena hakikat kita lahir didunia inipun adalah penderitaan. Roh yang berintikan rasa itu tak pernah bebas dari keterikatan, hanya saja Kesadaran mengajak kita untuk meningkatkan kulaitas keterikatan itu,dari yang bersifat kasar menuju yang halus, dari yang sempit menuju yang lebih luas. Masalahnya adalah, bila kita memperkuat kecendrungan keterikatan terhadap sensasi kenikmatin material maka diri kita akan semakin sulit untuk melepaskan diri dari dunia material, sementara kesadaran mengharapkan sang jiwa untuk meningkatkan dirinya untuk terlepas dari ikatan ikatan tersebut. Oleh karena itu belajar untuk Sadar dengan Keadaan Material yang bersifat Maya ini merupakan hal sangat penting untuk meningkatkan kualitas diri sehingga dengan harapan suatu saat nanti jiwa ini akan benar benar terlepas dari seluruh yang bersifat materi Duniawi.

\section{PEMBAHASAN}

\subsection{Dukha dan Perjalanan Hidup}

Sifat dari dunia adalah dualitas (rwabineda) Dia mengandung segala sesuatu dan lawannya: kesenangan dan kesedihan, kebaikan dan keburukan, cinta dan benci. Dengan mengalami semua ini, kita belajar dan berkembang, akhirnya mencari kebenaran yang mengatasi rwabineda itu. Hal yang demikian adanya merupakan kesimbangan yang merupakan konsep dasar dalam kehidupan. Semua yang ada baik dalam Macro Cosmos dan Micro Cosmos didasari oleh hal ini. Rwa Bhineda inilah yang menjadi dasar dari hukum keseimbangan alam semesta.

Ada tujuan suci bahkan dalam kehadiran dari penderitaan di dunia ini. Penderitaan tidak dapat sepenuhnya dihindari. Ia merupakan bagian alami dari kehidupan manusia dan merupakan bibit dari banyak pertumbuhan spiritualitas jiwa. Mengetahui hal ini orang yang bijaksana menerima penderitaan dari manapun, katakanlah misalnya karena topan, gempa bumi, banjir, kelaparan, perang penyakit dan tragedi yang tak dapat dijelaskan. Sama seperti api membara dalam perapian yang memurnikan emas, demikianlah penderitaan memurnikan jiwa hingga bersinar cahayanya. Demikian juga penderitaan memberikan kita kesadaran bahwa kebahagiaan yang sejati tidak ditemukan di dunia ini, karena kesenangan duniawi terikat secara tak terpisahkan dengan kesedihan, dan kebebasan duniawi dengan keterikatan. Menyadari ini, seorang pemeluk mencari guru kebenaran (satguru) yang mengajari untuk mengerti makna penderitaan, dan menuntunnya kedalam kesulitan yang disengaja dari sadhana dan tapa untuk menuju kepada kebebasan dari lingkaran pengalaman dalam wilayah dualitas (rwabineda). Kitab Agama menjelaskan: "Itu yang kelihatan sebagai dingin atau panas, segar atau busuk, nasib baik dan buruk, cinta dan benci, giat dan malas, yang dimuliakan dan dihina, kaya dan miskin, memilik dasar bagus atau buruk, semua itu adalah Tuhan sendiri; tiada lain dari Dia yang kita ketahui."

Ada Empat bekal terlahir sebagai manusia yang diberikan oleh Sang Pencipta agar dapat memahami kesadaran dualitas semesta yang sempurna.

- Tuhan membekali dengan suka agar kita bisa menikmati kehidupan ini sebagai sesuatu yang berharga.

- Bekal duka-lara agar kita tidak mudah melekat pada kehidupan ini hanya karena perasaan suka yang sedang dialami.

- Bekal Pati (kematian) dimaksudkan agar kita sadar bahwa kehidupan duniawi ini akan berujung pada kematian.

Maka nikmati kehidupan ini dengan bekal rasa suka, lalu pahami duka dan lara sebagai pembelajaran menuju penerimaan terhadap keniscayaan dualitas semesta. Jadikan kedua sbg pengingat agar tidak mudah melekat pada kehidupan duniawi yang tidak abadi ini. Dimana keempat bekal tersebut yang diharapkan akan membawa keselamatan menuju kesadaran 
semesta. Belajarlah tidak terlalu bahagia saat suka menghampiri, karena akan menjebak dalam kehidupnan duniawi.

Bergembiralah pada rasa suka itu sebatas untuk membantu bisa ikhlas bersyukur atas setiap hal yang membahagiakan, dan sebaliknya pada saat duka-lara-pati menghampiri. Dan harus disadari keempat bekal tersebut harus dikelola dengan baik, menuju kesadaran yang sempurna. Sehingga sebagaimana ditambahkan, pemahaman tentang samsara yaitu dengan kelahiran di bumi ini merupakan kesempatan untuk dapat meningkatkan kesucian yang telah dimiliki, sehingga pada suatu saat mencapai kesempurnaan yang abadi, bisa lebur bersatu dengan Penciptanya.

Karena itulah disebutkan penjelmaan atau reinkarnasi akan terus berlanjut sampai Jiwatman sadar akan hakekat dirinya sebagai Atman yang terlepas dari pengaruh awidya untuk mencapai Moksa yaitu kebahagiaan dan kedamaian yang abadi serta kembali bersatu kepada asalnya.

Dalam ajaran Hindu, bahagia dan penderitaan sesungguhnya bersumber dari dalam diri. Bertutur tentang bagaimana setiap individu melakukan respon atas objek dari luar. Untuk terhindar dari penderitaan, maka umat Hindu diajarkan untuk mengenali penyebab penderitaan tersebut. Karena dengan mengenali penyebab, maka pembenahan diri untuk terhindar dari penderitaan bisa dilakukan.

Dalam Chandogya Upanisad V.10.7 disebutkan Abhram bhutva megho bhavati, megho bhutva pravarsati, ta iha vrihiyava osadhi vanasvatayas tila-masa iti jayante, ato vai khalu durnis prapataram, yo yo hy annamatti yo retah sincati tasd bhuya eva bhavati.

(Chandogya Upanisad V.10.7)

"Setelah menjadi embun, mereka jadi mendung turunlah hujan. Mereka dilahirkan disini sebagi beras dan gandum, pepohonan dan tanaman jamu, pohon buah dan kacang kacangan. Dari sini pelepasan menjadi sangat sukar bagi siapapun yang menyantap makanan dan memetik buah, dia akan menjadi seperti dia. (Radhakrishnan, 2008:333)

Mantra tersebut mengisyaratkan bahwa jiwa yang mengalami kelahiran berupa tumbuh tumbuhan dapat menghambat pembebasan. Bagi setiap orang yang mengkonsumsi buah buahan tanpa mempersembahkan pada Tuhan akan mencapai kehidupan seperti yang ia makan, maksudnya adalah hidup dengan sifat sifat yang ia makan. Disamping mantra tersebut Chandogya Upanisad V.10.7 Menyatakan

Tad ya iha ramaniya-caranah, abhyaso ha yet te ramaniyam yonim apadyeran, brahmana-yonim va ksatriya-yonim va vaisya yonim va; atha ya iha kapuya-caranah abhyaso ha yat te kapuyam yonim apadyeran sva-yonim va sukara-yonim va candala-yonim va.

(Chandogya Upanisad V.10.7)

"Mereka yang melakukan perbuatan baik disini akan segere memperoleh kelahiran yang baik, kelahiran sebagai Brahma, kelahiran sebagi seorang Ksatriya tau kelahiran sebagai Vaisya. Tetapi mereka yang perbuatanya jahat kelahiran sebagai anjing, babi atau candala (Radhakrishnan, 2018:333-334)

Mantra tersebut juga menyatakan tentang hasil hasil perbuatan yang kita lakukan, perbuatan baik akan mendapatkan hasil yang baik sementara perbuatan buruk akan mengasilkan hasil yang buruk. Perbuatan baik dan buruk ini diperoleh pada siklus kelahiran dan kematian, kebahagian dan penderitaan ini menyebabkan keterikan dan Duhkha. bahkan perbuatan baik dan buruk ini berpengaruh pada kelahiran berikutnya. Apabila kelahiran berikutnya menurun maka proses pencapaikan kelepasan akan lebih lama lagi. Didukung pula dalam Atharva Veda IX.10.8 juga disebutkan:

\section{Jivo mrtasya carati svadhabih}

A varivarti bhuvanesu-antah

(Atharva Veda IX.10.8) 
“jiwa sebuah tubuh yang mati, mengambil bentuk yang lain (terlahir kembali) menurut perbuatan di masa lampaunya (akumalasi karmanya sendiri).

Mengambil bentuk bentuk (kelahiran) yang berbeda beda terus mengembara di alam semesta (Kurniawan, 2013: 55)

Mantra diatas sangat jelas menguraikan bahwa sang jiwa yang berada dalam tubuh tidak mengetahui hakita sang diri sejati, ia hanya mengetahui badan fisiknya saja sehingga ia terpenngaruh oleh duniawi baik harta benda, keluarga, maupun kedudukan. Segala keterikan itu akan menjebloskan jiwa dalam jurang penederitaan (Duhkha).

Dalam Yoga sutra Patanjali II.3 menyebutkan: "Avidyasmita raga dvesabhinivesah klesah", bahwa ada 5 penyebab penderitaan (Panca Klesa). Terdiri dari Awidya: Kebodohan, Asmita: Keakuan, Raga: Keterikatan, Dwesa : Kebencian, Abhiniwesa : Ketakutan dan kematian. Jika ingin terbebas dari penderitaan atau ingin senantiasa hidup bahagia, maka Hindu mengajarkan kita untuk melepas diri dari 5 belenggu penyebab penderitaan. Mematangkan spirit dalam diri tentu menjadi lebih penting, dibandingkan mengejar pemenuhan keluar diri. Bahagia ataupun Derita, bersumber dari dalam diri kita masing-masing.

\subsection{Tuhan dan Hukuman bagi Pendosa}

Tuhan adalah kebaikan yang sempurna, cinta dari kebenaran. Dia tidak pemarah dan pembalas dendam. Dia tidak mengutuk dan menghukum orang yang berbuat salah, Kecemburuan, pembalasan dendam dan kepura-puraan adalah sifat-sifat dari manusia yang naluriah (instingtif), bukan sifat-sifat Tuhan. Tidak ada alasan untuk takut pada Tuhan, yang gerak "tangan kanannya", abhaya mudra, berarti "jangan takut" dan "tangan kirinya" mengundang untuk mendekat. Tuhan senantiasa bersama kita, bahkan ketika kita tidak sadar tentang kehadiran sucinya. Dia adalah cintaNya sendiri. la adalah merupakan pemekaran dari dirinya sendiri; dan Tuhan tidak pernah berpisah darinya dan tidak juga dibatasi olehnya (pemekaran itu). Ketika kita bertindak salah, kita menciptakan karma negatif untuk diri kita sendiri dan harus menjalani hidup menderita untuk memenuhi hukum karma. Karma demikian boleh jadi sangat menyakitkan, tapi itu merupakan buah dari pikiran dan perbuatan kita. Tuhan tidak pernah menghukum kita, bahkan sekalipun kita tidak percaya kepadanya adalah melalui pemujaan dan meditasi kepada Tuhan penderitaan yang kita ciptakan sendiri akan dilembutkan dan diperingan. Tuhan adalah Tuhan dari semua orang percaya dari semua agama, juga Tuhan bagi semua orang yang tidak percaya. Tuhan tidak menghancurkan orang jahat dan menebus orang yang benar; tapi memberikan kebebasan bagi semua jiwa.

Ketika kita tidak berpikir, berbicara dan bertindak secara bijaksana, kita menciptakan karma yang negatif dan membawa penderitaan bagi diri kita sendiri dan orang lain. Kita menderita bila kita bertindak secara naluriah dan secara intelektual tanpa bimbingan kesadaran utama. Kita bahagia, tenang dan mantap bila kita mengikuti tingkah laku yang baik, bila kita mendengar hati nurani kita, suara penuh pemahaman dari jiwa kita. Pikiran yang sangat sadar (supercounscious mind) dari jiwa kita, mengetahui dan memberi inspirasi untuk tingkah laku yang baik, dari padanya keluar budaya yang halus dan berkembang. Tindakan salah dan kejahatan menjauhkan kita dari Tuhan, jatuh dalam kegelapan dari kebimbangan, keputusasaan dan pengutukan diri sendiri. Hal ini membawa para asura ke sekitar kita. Kita berada diluar harmoni dengan diri kita dan keluarga kita dan harus kawan ditempat lain, diantara mereka yang juga kasar, lalai, serakah dan tidak memiliki pengendalian atas diri. Dalam persekutuan yang buruk ini, karma-karma baru yang membebani diciptakan, karena tingkat laku yang baik tidak diikuti. Papa ini bertumpuk, membutakan kita terhadap kehidupan beragama yang pernah kita jalani. Penyesalan dan menyerahkan diri kita kepada wara nugraha Tuhan adalah satu-satunya 
jalan untuk membebaskan diri kita dari orangorang jahat, mereka yang betingkah laku buruk. Sangatlah beruntung bahwa Tuhan kita penuh kasih dan cinta kepada para pengikutnya WedaWeda menjelaskan, "Pikiran itu dikatakan terdiri darl dua lapis yang suci dan juga yang tidak suci; yang tidak suci bersatu dengan nafsu, yang suci bebas sepenuhnya dari keinginan (untuk mementingkan diri sendiri)."

Dalam Chandogya Upanisad V.10.7

Menyatakan

Tad ya iha ramaniya-caranah, abhyaso ha yet te ramaniyam yonim apadyeran, brahmana-yonim va ksatriya-yonim va vaisya yonim va; atha ya iha kapuya-caranah abhyaso ha yat te kapuyam yonim apadyeran sva-yonim va sukara-yonim va candala-yonim va.

(Chandogya Upanisad V.10.7)

"Mereka yang melakukan perbuatan baik disini akan segere memperoleh kelahiran yang baik, kelahiran sebagai Brahma, kelahiran sebagi seorang Ksatriya tau kelahiran sebagai Vaisya. Tetapi mereka yang perbuatanya jahat kelahiran sebagai anjing, babi atau candala (Radhakrishnan, 2018:333-334)

Mantra tersebut menggambarkan tentang hasil hasil perbutan yang dilakukan. Setiap perbuatan yang baik akan memperoleh hasil yang baik sementara perbuatan yang buruk akan memperoleh hasil yang buruk pula, demikianlah hal yang harus kita sadari ketika kita sebagai manusia mendapatkan hal yang buruk atau tidak baik itu tiada lain adalah buah hasil perbuatan diri sendiri yang harus diterima tetapi seringkali manusia tidak bisa secara dewasa menerima hal tersebut, menganggap hal buruk itu tidak pantas untuk ia terima dengan anggapan Tuhan tidak adil atau hal tersebut merupakan Hukuman Tuhan, hal inilah secara mendasar kita harus sadari Tuhan tidak pernah campur tangan dalam segala urusan manusia, Tuhan hanya memberikan Karma yang harus kita terima dari perbuatan perbuatan yang kita telah lakukan, tidak ada yang salah di dunia ini karena sudah demikian jalan karma yang harus ada dan pula harus diterima.

\subsection{Apakah Mungkin Lepas Dari Dukha}

Jadi kita ingin maju. Hal ini menyebabkan munculnya pertanyaan berikutnya: bagaimana untuk mencapai kebahagiaan abadi ini? Dalam rangka untuk mencari kebahagiaan yang lebih tinggi, kita harus berusaha untuk mencari Tuhan atau mencoba untuk mengetahui diri kita sendiri. Jika kita diam-diam berlatih, kita bisa mencapai kebahagiaan itu. Menurut Hindu, tidak ada yang dihukum. Tidak ada yang buruk. Tidak ada yang berdosa. Semua dosa adalah kesalahan. Semua adalah ahli waris untuk kebahagiaan abadi. Semua bisa mencapainya. Hal ini karena, semua kebahagiaan. Adapun kesedihan, penderitaan, dosa, hanya penutup luar. Setiap aktivitas karma seseorang didasari oleh keinginan (Iccha). Timbulnya keinginan akan direspon oleh pikiran. Pikiran inilah yang akan mengambil keputusan untuk melakukan tindakan dalam bentuk ucapan ataupun tindakan jasmani. Keputusan pikiran sangat ditentukan oleh pengetahuan (jnana), kebijaksanaan (wiweka), serta pengalaman hidup serta karma wasana seseorang. Ada lima kepastian dari hukum sebab-akibat semesta, atau hukum karma, yaitu:

1. Semua sebab akan menghasilkan akibat. Jika kita mengalami kesengsaraan [misalnya jatuh sakit, ban motor pecah di jalan, kecurian, kecelakaan, kena tipu, dsb-nya], hal itu pasti merupakan akibat dari karma-karma buruk kita di masa waktu sebelumnya. Sebaliknya jika kita mengalami kebahagiaan, hal itu pasti merupakan akibat dari karma-karma baik kita di masa waktu sebelumnya. Kaitan erat antara perbuatan atau perkataan kita, yang kelak akan menghasilkan kesengsaraan atau kebahagiaan, sangat penting untuk dipahami sebagai hukum yang bekerja di alam semesta ini. 
2. Semua akibat berasal dari sebab. Jika kita tidak melakukan suatu perbuatan atau perkataan tertentu, kita tidak akan mengalami akibat-akibatnya. Misalnya ada sebuah kecelakaan bis dimana banyak orang yang tewas, tapi ada juga beberapa orang yang bisa selamat. Ini disebabkan karena mereka tidak melakukan sebab-sebab yang memungkinkan mereka tewas dalam kecelakaan itu, jadi mereka tidak mengalami akibat-akibatnya.

3. Adanya kepastian akibat. Jika kita melakukan suatu perbuatan atau perkataan tertentu, akibat karmanya tidak akan lenyap dengan sendirinya. Pada suatu waktu karma itu pasti akan datang. Mungkin saja perlu waktu 100.000 [seratus ribu] tahun, tapi karma itu pasti tetap akan datang.

4. Adanya peningkatan dari akibat. Karma itu dapat berdampak berantai. Dari perbuatan atau perkataan kecil, kemudian akibat-akibat yang sangat besardapatmuncul. Misalnya kita berkata atau bertindak kasar pada pasangan kita, kemudian kita tidak bicara satu sama lain. Semakin lama kita membiarkannya tanpa mencoba menyelesaikan masalahnya, maka semakin besar kemarahan terasa dan semakin sulit atau rumit masalahnya dapat diselesaikan. Selain itu, akibat karma tidak selalu terjadi seperti laju sebuah garis lurus. Berbagai perbuatan atau perkataan dapat berakibat sekaligus pada satu hal saja. Demikian juga sebaliknya, satu perbuatan atau perkataan dapat berakibat banyak hal pada berkali-kali masa kehidupan. Misalnya kita memfitnah seorang Guru suci yang asli, atau pembawa ajaran dharma yang asli [ajaran dharma yang sesuai dengan kenyataan kosmik], maka akibatnya selama berkali-kali masa kehidupan kita akan tenggelam dalam kegelapan avidya.

5. Karma buruk bisa dihapuskan. Jika kita melakukan suatu perbuatan atau perkataan yang berdampak dhukacitta [merugikan, menyengsarakan atau menyakiti mahluk lain], pada suatu waktu karma itu pasti akan datang. Karena dalam hukum karma, semua sebab akan menghasilkan akibat dan akibat itu suatu saat pasti akan datang. Kecuali jika kita tekun melaksanakan sadhana-sadhana yang dapat menghapus karma buruk.

Jika kita mengalami kesengsaraan [misalnya jatuh sakit, ban motor pecah di jalan, kecurian, kecelakaan, kena tipu, dsb-nya], sudah pasti hal itu merupakan akibat dari karma-karma buruk kita di masa waktu sebelumnya. Tapi ini tidak berarti bahwa jika di masa waktu sebelumnya kita pernah melakukan perbuatan atau perkataan yang berdampak dhukacitta, maka kemudian semuanya akan menghasilkan akibat kesengsaraan. Tidak selalu. Karena karma-karma buruk dapat dihapuskan melalui ketekunan kita melaksanakan sadhana-sadhana yang dapat menghapus karma buruk.

Jika kita telah tekun menahan diri dari melakukan kejahatan dan banyak melakukan kebaikan-kebaikan, serta kita sangat tekun melakukan sadhana-sadhana yang dapat menghapus karma buruk, maka sesungguhnya tidak ada lagi bahaya yang harus kita takutkan. Bahkan jika kita pergi ke suatu tempat penuh bahaya, dengan banyak penjahat kejam berkeliaran di sana, kita tidak akan mengalami perampokan, karena karma-karma buruk kita sebagai penyebab yang memungkinkan kita dirampok telah terhapuskan.

Karma tidaklah bersifat statis atau mutlak tidak berubah, tapi bersifat dinamis. Tidak ada sesuatu yang kekal di alam semesta ini, semuanya ada dalam gerak dinamis yang selalu berubah, termasuk karma. Sehingga karma setiap mahluk juga berubah-ubah, yang semata-mata ditentukan oleh apa pilihan perkataan dan perbuatan kita masing-masing.

Karma adalah hukum sebab dan akibat. Sebab dan akibat berarti setiap pengalaman bahagia dan sengsara yang kita alami dalam kehidupan pasti ada sebabnya. Jika sebabnya diringankan maka ringan juga akibatnya. Jika sebabnya 
dapat diatasi [dihapuskan] dengan melaksanakan sadhana-sadhana yang dapat menghapus karma buruk, maka akibatnya-pun juga akan lenyap. Kebahagiaan dapat dihadirkan dan penderitaan juga dapat dihindari, jika kita merubah sebabsebabnya.

Anda sekarang dapat mengatakan: "Saya mengerti bahwa apa yang saya menikmati sekarang tidak kebahagiaan sejati. Saya juga mengerti bahwa saya harus mencari kebahagiaan yang lebih tinggi. Tapi, apa ada bukti bahwa ada kebahagiaan yang lebih tinggi? Dapatkah saya mendapatkan rasa itu di sini? "Tentu saja bisa! Ada teknik sederhana untuk mendapatkan kebahagiaan ini. Ini adalah ini: Menyerah keinginan, dan Anda akan bahagia. Saat ini, Anda memutuskan. Saya akan memberikan semua keinginan. Saya tidak akan menginginkan sesuatu. Semua ketegangan akan pergi, semua masalah akan pergi, dan Anda akan berada dalam kedamaian. Keinginan membuat kita berputar-putar, tidak mencapai apaapa. Mari kita menyerahkan keinginan, dan kita akan langsung dalam damai.

Secara sepintas kita dapat menyebutkan beberapa aturan yang indah dan kehidupan yang sederhana.Harapmenjagakeinginandalampikiran, jika Anda ingin memimpin diri dan hidup damai di dunia. Jangan mencari apa-apa. Jika Anda mencari sesuatu, Anda akan berada dalam penderitaan. Jadi tidak ada gunanya mengkhawatirkan sesuatu apa pun, karena itu akan membawa kesengsaraan dan tidak sukacita. Mari kita meninggalkan segala sesuatu untuk Tuhan, maka itu adalah cara terbaik untuk mencapai kebahagiaan. Mari kita ingat prinsip sederhana. "Saya menderita karena pria ini tidak mencintai saya. Saya menderita karena saya tidak mendapatkannya. Saya kesakitan karena orang ini tidak berterima kasih padaku."

Semua sikap itu salah. Berikan pergi ide-ide tersebut, dan Anda akan berada dalam kedamaian. Anda dapat menggunakan energi Anda untuk mencari yang lebih tinggi. Berikut adalah beberapa langkah praktis untuk mencapai kebahagiaan dan ketenangan pikiran. Hindu mengatakan kepada kita agar tidak memiliki keinginan dalam pikiran. Putuskan sekarang: Mulai saat ini saya tidak akan memiliki keinginan untuk apa pun. Apa pun yang datang, biarkan datang. Ini akan langsung membawa kedamaian. Ini adalah tahap awal dari kebahagiaan.

Jangan khawatir bahwa Anda adalah orang berdosa. Ini adalah salah satu kendala terburuk untuk sukacita. Menyerah khawatir. Apa pun itu masa lalu adalah masa lalu. Tuhan bukanlah sejarawan dan hakim kecil untuk menilai Anda menyangkut apa yang Anda lakukan. Dosa adalah kesalahan yang dilakukan manusia. Seperti seorang penari terus menangis karena ia jatuh sepuluh kali ketika dia sedang berlatih menari. Tetapi dia akan terus menari dan akan berhasil. Jadi dalam hidup kita jatuh seratus kali. Mari kita tidak khawatir tentang hal itu.

Jangan khawatir jika seseorang membenci atau seseorang tidak menyukai Anda. Biarkan mereka membenci Anda. Biarkan mereka tidak menyukai Anda. Dunia ini luas. Ada jutaan orang di sini. Biarkan semua orang pergi dengan cara mereka sendiri. Melepaskan segala sesuatu dan Anda akan bebas dan bahagia. Dunia ini adalah tidak kekal. Mari kita mencari sesuatu yang permanen, Brahman. Jadi berpeganglah selalu pada Tuhan. Ini akan membawa perdamaian. Kendalikan diri Anda. Memberikan cinta Anda hanya kepada Tuhan dan tidak ada yang lain. Ini yang akan membawa Anda pada kebahagiaan besar.

Jika beberapa masalah datang dalam hidup Anda, jangan mulai khawatir. Khawatir akan membuat hal-hal buruk. Bayangkan bahwa Anda mengambil masalah yang di tangan Anda seperti buah, dan menawarkan kepada Tuhan dan berdoa. Ketika khawatir datang, segera singkirkan dan tekun berdoa. Ini akan membantu Anda dalam segala hal. 
Dalam geguritan Dharma Prawerti dijelaskan untuk melepaskan diri dari dukha melalui cara mencari guru yang mapan selain dengan bantuan guru spiritual, Chandogya Upanisad mengurakan cara terbebas dari belenggu Dukha yakni dengan pengetahuan tentang atman, Chandogya Upanisad VII.25.2 menguraikan

Athata atmadesa eva atmaivadhastat, atmoparistat atma pascat, atma purastat, atma daksinatah, atmottaratah, atmaivadam sarvam iti. Sa va esa evam pasyann evam manvana evam vijanam atma-ratir, atma-krida atma-mithuna atmanandah sa svarad bhavati tasya sarvesu lokesu kama-caro bhavati, atha ye nyathato viduh, anya rajanas te ksayya-loka bhavanti. Tesam sarvesu lokesu akama-caro bhavati.

Chandogya Upanisad VII.25.2

Sekarang berikutnya ajaran mengenai atman, atman sesungguhnya ada dibawah, atman ada diatas, atman ada dibelakang, atman ada dibelakang, atman ada di utara, atman ada di selatan. Atman sebenarnya adalah suluruh alam ini. Dia sesungguhnya melihat alam ini, yang mengerti hal ini mempunyai kenikmatan kepada atman, dia yang memiliki kenikmatan pada atman, dia yang memiliki kegembiraan pada atman, dia terbebas dia memiliki kebebasan tiada terbatas pada seluruh alam. Tetepi mereka yang berfikir berbeda dari hal ini akan tergantung pada orang lain, mereka telah hidup pada dunia fana. Pada semua alam mereka tidak mempunyai kebebasan

Mantra tersebut diatas sangat jelas menyatakan mereka yang mengerti tentang atman yang meliputi alam semesta, akan mengalami kebahagian tidak terbatas. Sesungguhnya yang tidak terbatas itulah Tuhan sebab tuhan melamapaui segala yang ada. Dengan demikian Chandogya Upanisad menganjurkan kepada setiap orang untuk mengetahui dan menghayati tentang hakikat sejati sang diri, untuk terlepas dari Dukha. Tujuan hidup adalah untuk mengenal Brahman. Kita dila-hirkan kembali dan menderita lagi dan lagi, hanya karena kita tidak mengenal Tuhan atau
Kebenaran. Ini adalah prinsip dasar agama Hindu. Hindu mengatakan bahwa kita di dunia ini tidak untuk menikmatinya dan menderita. Kita di sini untuk mengenal Brahman (Tuhan). Mengapa kita harus tahu Tuhan? Kita harus mengenal Tuhan karena alasan sederhana bahwa kita adalah Tuhan. Kita adalah ilahi. Untuk mengenal Tuhan kita harus berlatih pengendalian diri dan melakukan praktik spiritual.

Ketika kita berada di dunia, mencari kebahagiaan duniawi, kita mendapatkan kebahagiaan yang sangat terbatas, tapi rasa sakit yang hebat. Ketika kita mencari Tuhan, kita mendapatkan ketenangan dan kebahagiaan besar, yang merupakan sifat sejati kita. Kita tidak perlu mengemis atau meminjamnya. Ini adalah sifat kita yang sebenarnya. Karena kita berpikir kita terbatas, kita menderita. Ketika kita menyerah keterbatasan, kita tahu kebahagiaan

Cara untuk menghadapi karma ialah dengan berhubungan baik dengan karma yang artinya biarkan putaran karma mengalir bersama diri kita sendiri. Karena mereka yang mengalir bersama putaran karmanya maka bhatinnya akan damai dan lebih mudah bahagia. Karena akan memunculkan sifat ketulusan dan keihklasan dalam diri dalam menjadi kehidupan. Misalnya, Jika kita punya impian menjadi orang yang kaya raya akan tetapi setelah bekerja keras hasil yang didapat (karma) hanyalah hidup sederhana. Maka mengalirlah bersama karma dengan mensyukuri apa yang kita miliki dengan mengurangi mengeluh dan tetap selalu bekerja keras. Untuk diketahui bahwa Karma memiliki beberapa sifat yaitu :

1. Abadi: keberadaan hukum ini dimulai pada saat alam semesta ini ada dan akan berakhir pada saat pralaya (kiamat). Walaupun demikian, tidak ada seorang pun yang tahu kapan penciptaan dan berakhirnya alam semesta ini. Inilah yang menjadi rahasia Pencipta. Penciptaan alam semesta bersamaan dengan penciptaan hukumhukum yang bekerja secara amat sangat 
canggiiiih sekali dan memiliki ketepatan yang tiada tara. Hukum grafitasi diciptakan bersamaan dengan diciptakan-Nya alam semesta. Kebetulan saja ada mahluk Tuhan yang bernama Isaac Newton yang menggunakan akal/pikiran dan budinya dengan baik, sehingga berhasil mengungkap "keberadaan" dan "cara kerja" hukum ini, walaupun sebelumnya pun kalau ada benda yang dilemparkan ke atas, pasti akan jatuh lagi ke bumi. Lalu manusia lain mengakuinya dan menamakan hukum ini dengan "hukum Newton".

2. Universal: hukum ini berlaku pada setiap ciptaan Tuhan,. Di mana pun berada, bagaimanapun wujud ciptaan itu, hukum ini berlaku baginya. Mempercayai atau tidak mempercayai keberadaan hukum ini, jika masih berada di alam semesta ini, hukum ini tetap bekerja baginya. Kalau ia berbuat baik, hasilnya pasti baik juga, dan hasilnya dia juga yang akan menikmatinya. Kalau sebaliknya, ya demikian juga. Kalau ada anggapan bahwa hanya kalau berbuat dosa saja kena hukum karma, ya inilah sebuah kesalahanpahaman

3. Berlaku sepanjang zaman: pada zaman apa pun hukum ini tetap berlaku dan tidak mengalami perubahan. Baik pada zaman satya (kerta) yuga, treta yuga, dwapara yuga, kali yuga hukum ini tetap berlaku. Kalau di zaman sekarang (yang diidentifikasi sebagai zaman kali, zaman terakhir) sepertinya hukum karmaphala ini tidak lagi efektif bekerja, ya anggapan itu keliru lagi. Kalau kelihatan bertentangan, itu hanya penglihatan dan analisis manusia yang sangat terbatas, yang tidak mampu melintasi dan menggabungkan berbagai fakta dari zaman lainnya dengan lengkap. Demikian singkatnya pengetahuan dan pemahaman manusia tak mampu mengungkap lintas zaman tadi, karena rentang waktunya demikian lamaaaaa sekali, yang ribuan bahkan jutaan kali rentang umur manusia. Sedangkan pengetahuan tentang diri dan perbuatannya semasa bayi atau anak-anak saja tak tersimpan lagi di memorinya, bagaimana mau menyimpan peristiwa lintas zaman?

4. Sempurna: karena kesempurnaannya, kerja hukum ini tak dapat diganggu-gugat, diubah atau dipaksa berubah. Sifatnya konstan dan tidak berubah dari zaman ke zaman. Hukum ini hanya dapat "ditaklukkan"dengan cara mengikuti alur kerjanya, diiringi dengan keihklasan yang dalam. Kalau menurut penglihatan dan analisis manusia, dia menerima hasil yang tidak sesuai dengan perbuatannya, bisa dipastikan penglihatan dan analisisnya itu tidaklah lengkap. Kalau rasa-rasanya telah dan selalu berbuat baik, lalu hidupnya begitu-begitu saja atau malah menderita sepanjang hayat, mesti ada yang belum terungkap. Ada mata rantai kausalitas yang menyebabkan demikian. Itulah yang tak mampu dijangkau nalar, pikir, dan budi manusia. Karena bak iklan sebuah produk, hukum ini mengikuti yang berbuat atau yang berkarma kapan dan di manapun berada.

Mungkin kita mengira bahwa karma yang kita peroleh sudah diatur atau ditentukan Tuhan. Lantas Siapakah Penentu Karma Kehidupan Akan tetapi dari apa yang dijelaskan dalam SAMSARA yaitu: dalam ajaran agama Hindu manusia itu svatantra katah, yaitu mahluk yang sepenuhnya bebas, memilik kehendak bebas dan sepenuhnya bertanggung jawab atas semua perbuatannya sendiri. Jadi hukum karma bukanlah sebagai nasib "takdir Tuhan" melainkan kita sendirilah yang sepenuhnya menentukan nasib kita sendiri. Baik buruknya pada kehidupan sekarang merupakan Karma (buah perbuatan) dari kehidupan sebelumnya dan saat ini. Maka mari sama-sama benahi diri, pilih yang baik, lakukan yang baik untuk kelak mendapatkan karma yang baik pula. 


\section{Simpulan}

Kehidupan di dunia ini adalah suatu bentuk penderitaan, hal ini disebabkan karena semua mahkluk terikat oleh unsur unsur duniawi. Ketika roh masih terjangkit phala maka siklus kelahiran dan kematian dengan senang hati menunggu kehadiran sang roh. Ketika sang roh telah mampu terlepas dari ikatan yang bersifat menjerumuskan sang roh dalam jurang kesengsaraan (Dukha), saat itulah ia akan mencapai kekebasan abadi (Moksha). Dalam Chandogya Upanisad Dukha yaitu terikatnya roh dalam badan yang bersifat material. Ketika roh diikat oleh indria-indria, maka berjuta-juta keinginan muncul. Segala keterikatan akan berbagai keinginan inilah yang menjebloskan jiwa dalam jurang kesedihan (duhkha). Ia akan selalu berbuat untuk memenuhi indriyanya, setiap perbuatan inilah yang mendukung sang jiwa mendapat berbagai jenis badan, ketika badan yang diperoleh menurun maka proses pencapaian kebebasanya pun akan semakin lama

Cara membebaskan diri dari ikatan dukha menurut chandogya upanisad yaitu dengan mengerti tentang atman yang meliputi alam semesta, akan mengalami kebahagian tidak terbatas. Karena Sesungguhnya yang tidak terbatas itulah Tuhan sebab tuhan melamapaui segala yang ada. Dengan demikian Chandogya Upanisad menganjurkan kepada setiap orang untuk mengetahui dan menghayati tentang hakikat sejati sang dir, untuk terlepas dari Dukha.

\section{DAFTAR PUSTAKA}

Radhakrishnan, S. 2008. Upanisad Upanisad Utama. Terjemahan Agus S Mantik. Surabaya: Paramita.

Putra, Ngakan Putu. 2014. Kamu Adalah Tuhan. Jakarta: Media Hindu.

Kurniawan, I Nyoman. 2013. Samsara: Perjalanan Sang Jiwa dalam Kehidupan dan Kematian. Paramita: Surabaya.
Prabhupada, Sri Srimad A.C, Bhaktivedanta Swami. 2002. Kembali Lagi: Sains Reinkarnasi. Terjemahan oleh Tim Penerjemah 2006. Tanggerang: Hanuman Sakti.

Pudja, Gede 1999. Theologi Hindu (Brahma Widya). Surabaya: Paramita. 